\title{
地球温暖化による海面上昇がゼロメートル地帯の地下水環境に 及ぼす影響に関する実験的研究*
}

\author{
増岡健太郎 $* *$. 藤縄克之 $* * *$.古川正修 $* * *$. \\ 長野宇規 $* * * *$. 渡辺紹裕 $* * * * *$
}

\section{Experimental studies for identifying the impacts of sea-level rise caused by global warming on groundwater environment in areas below sea-level*}

\author{
Kentaro MASUOKA **, Katsuyuki FUJINAWA ***, Masanao FURUKAWA****, \\ Takanori NAGANO $* * * * *$ and Tsugihiro WATANABE
}

\begin{abstract}
According to IPCC, global warming may bring about rise in mean sea-level by $9 \mathrm{~cm}-88 \mathrm{~cm}$ at the end of $21^{\text {st }}$ century. Because the Japanese archipelago is surrounded by sea and important socioeconomic activities concentrate in areas below sea-level, it is prerequisite to predict influences of sea-level rise on groundwater systems in coastal aquifers. By conducting laboratory experiments, impacts of sea-level rise on coastal groundwater systems were investigated together with the effect of conservative measures. These experiments are specially characterized by the domain of glassbeads with inclined surface, which allows surfacial ponding of water and installation of an impermeable barrier in the domain to set back salt water intrusion. By these experiments, it is revealed that the sea-level rise causes acceleration of salt-water intrusion in coastal aquifers and inundation of low-lying areas, and that impermeable barriers are effective for preventing salt water intrusion but at the expense of inundation.
\end{abstract}

Key Words: Salt water intrusion, Surface seepage, Areas below sea-level, Sea-level rise, Inclined-surface experiments

2003年度日本地下水学会春季講演会において一部発表

大成建設(株)技術センター（

Technology Center, Taisei Corporation

*** 信州大学工学部

Faculty of Engineering, Shinshu University

**** 国際航業(株)

Kokusai Kogyo Co., LTD.

***** 総合地球環境学研究所

Research Institute for Humanity and Nature 


\section{要旨}

IPCCによれば、地球温暖化により 21 世紀末には平均海面が $9 \mathrm{~cm} \sim 88 \mathrm{~cm}$ 上昇する。日本列島は海 に囲まれ、重要な社会経済活動がゼロメートル地帯に集中しているため、海面上昇が海岸帯水層中 の地下水システムに与える影響を解明する必要がある。本研究では、海面上昇が海岸地下水システ ムに与える影響および保全対策の効果を調べるため、室内実験を実施した。実験では特に表面湛水 が可能なようにガラスビーズ充填域の表面を傾斜させるとともに、充填域内部に塩水浸入を抑止で きるような不透水壁を設置した。これらの実験より、海面上昇が海岸帯水層への塩水浸入とゼ口 メートル地带での地表面湛水を加速させること、不透水壁は塩水浸入防止に効果的である一方、地 表湛水が発生することが明らかになった。

キーワード：塩水浸入、地表浸出、ゼロメートル地帯、海面上昇、傾斜面実験

\section{1.はじめに}

IPCC 第 3 次評価報告書 (2001) によれば、1990 年から 2100 年までの間に地球の平均地上気温は $1.4 \sim 5.8^{\circ} \mathrm{C}$ 増加し、それに伴う極地域の水床の 融解や海水の膨張により地球の平均海面水位は 9 $\mathrm{cm} \sim 88 \mathrm{~cm}$ 上昇すると予測されている。

海面の上昇は、標高の低い島嶼や沿岸低地带の 水没、氾濫の危険性の増大、海岸の侵食、河川で の塩水遡上、生態系の絶滅、さらには地下水の塩 水化や陸域への塩水浸出など自然環境にさまざま な影響をもたらす。また、海面上昇がもたらす影 響は自然環境のみにとどまらず、防災システムや 交通施設などのインフラ、社会経済システムなど 広範囲におよぶ。

環境庁（1994）によれば、現在の我が国のゼロ メートル地帯（満潮水位より低い地帯）の総面積 は861 $\mathrm{km}^{2}$ 、蓄積されている総資産は54兆円、居 住人口は 200 万人であり、海水面が $1 \mathrm{~m}$ 上昇する と、影響を受ける総面積は $2,339 \mathrm{~km}^{2}$ 、総資産は 109兆円、人口は410万人に達すると推定されてい る。首都圈、近畿圈、中部圈など、我が国の経済 基盤を支え、多くの国民が居住する沿岸域を高潮 や津波などから守るためには、防潮堤のかさ上げ などを含めたインフラ整備が必要となる。

しかし我が国では、村下（1982）が地下水の塩 水化に関する実態を報告している程度で、帯水層 を経由して防潮堤下部から内陸部に浸出してくる 浸出水や地下水の塩水化についてはほとんど知見 が集積されていない。一方、海面上昇の脅威に曝
されているオランダでは、応用地球科学研究所 （TNO）が中心となり「21世紀の水管理計画」の一 環として地下水環境に関するデータベースの構築 や数值解析手法を用いた予測を開始している (TNO, 2003)。また、Essink and Schaars (2002) は、密度依存地下水流解析コードMOCDENS3D を用いて、地球温暖化が海面下に位置するオラン ダ・ラインランド地域の地下水システムに与える 影響を予測したりしている。

未知な現象の解明や数值解析モデルの妥当性の 検証に砂箱などを用いた実験が有効であるが、本 研究では、海面上昇がゼロメートル地带における 海岸带水層中の地下水システムに及ぼす影響を俯 瞰的に理解し、数值解析手法開発時のベンチマー クとして利用するために、水槽にガラスビースを 充填して一連の塩水浸入実験を実施した。特に、 実験で解明したい要点は、次の 2 点である。

(1)細川ら（1989）は、被圧帯水層を想定した実 験装置を用いて塩水浸入実験を実施している。し かし、ゼロメートル地帯を想定して充填試料上面 を傾斜させ、地表湛水が発生するような設定で 行った塩水浸入実験は著者の知る限り皆無であ る。そこで本研究では、充填試料上面を開放した 水平面実験と傾斜面実験を実施し、塩水浸入およ び湛水地表水と浸透流との交流を明らかにする。

(2)宮古島では地下ダムが建設されて水資源の確 保や海岸地域における塩水浸入阻止に役立てられ ている。このような基盤の浅い島嶼などでは、基 盤で完全止水する地下ダム方式が機能するが、地 下ダム方式は基盤が深い場合などには技術面や費 
用面で必ずしも有効とは限らない。このような完 全止水方式に代わる方法として、基盤まで止水し ない不完全貫入壁の効果を検討する。

\section{2. 塩水浸入に用いた実験装置}

\section{1 実験水槽}

図 1 に塩水浸入実験に用いた装置の概要を示 す。水平面実験用装置は、水槽内部にガラスビー ズを充填し、試料上面を水平にしたものである。 また、傾斜面実験用装置は、ゼロメートル地帯に おける海面上昇が地表への地下水の浸出と湛水排 除の影響を調べるために試料上面を傾斜させたも のである。

図 2 は実験水槽本体の詳細図で、装置本体の正 面と背面には厚さ $10 \mathrm{~mm}$ の透明アクリル板を使用 した。試料充填部の高さは $400 \mathrm{~mm}$ 、幅は $700 \mathrm{~mm}$ 、 奥行きは $20 \mathrm{~mm}$ で、左側に淡水槽（図 1 の9)、右 側に塩水槽（図 1の(10) を設け、試料充填槽と塩 水および淡水槽との境には金網を貼り付けたアル ミパンチ板（図1の(11)）を設置した。なお、傾斜 面実験では、ゼロメートル地帯の塩水浸入現象と その対策を検討するため、ゼロメートル地帯にお ける防潮堤を想定して塩水槽側のアルミパンチ板 上部150mm にビニールテープとアルミテープを

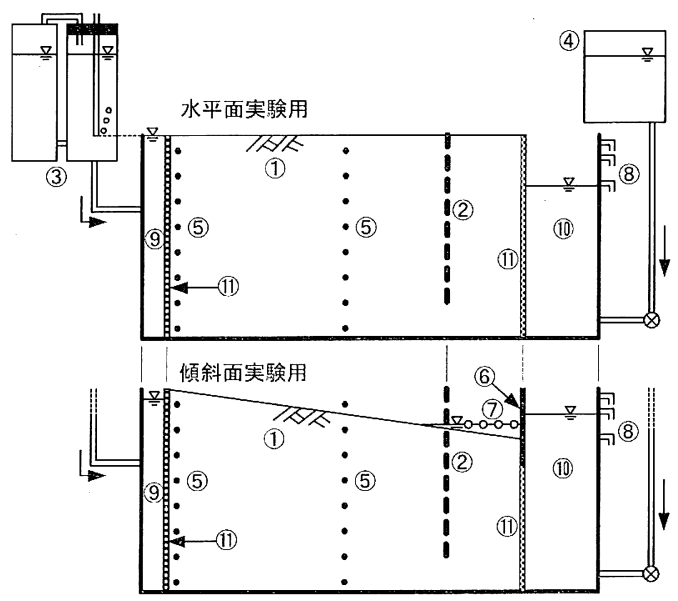

(1)試料充填槽 (2)不完全貫入壁 (3)淡水マリオット (4)塩水タンク (5)卜レーサ一注入孔（6)遮水壁（7)湛水排水孔（8)余水吐 (9)淡水槽 (10)塩水槽 (11)アルミパンチ板

\section{図 1 実験装置概略図}

Fig. 1 Plan of experimental device
巻いて不透水構造とした（図 1 の6)。なお、水 漏れを防止するため、ジョイント部には溝を設 け、ナイロン製のチューブを挟み、さらにグリー スを塗布した。

水槽の前面パネルと後面パネルには上端より下 端方向に長さ $350 \mathrm{~mm}$ 、幅 $1.5 \mathrm{~mm}$ 、奥行き $3.0 \mathrm{~mm}$ のスリットを設け、不完全貫入止水壁による塩水 浸入阻止効果を調べる実験においては、防水用に グリースを塗布したのちアルミ製板（図10(2) を挿入した。なお、貫入壁深度を変化させて多段 階で実験を行うため、貫入壁設置部は可動式とし た。

淡水槽の水位が正確に制御できるようにマリ オット（図1の(3) を通して充填槽内部に淡水を 補給するが、淡水の流出により塩水槽の塩分が低 下しないように、塩水槽余水吐（排水口）より高 い位置に設置した大型の塩水補給タンクから塩水 槽下部にとりつけた給水口に塩水が充分に補給で きるようにした。したがって、塩水槽の塩水は排 水口を水面とする静水圧分布をとらないため、以 下では塩水槽の条件を排水口の位置で表すことに する。なお、塩水槽の水位を段階的に変えるた め、塩水槽下部より $300 \mathrm{~mm} 、 350 \mathrm{~mm} 、 380 \mathrm{~mm}$ の 位置を中心に排水口を設置した。

なお、資料充填槽の前面には、外径 $2.1 \mathrm{~mm}$ 、 内径 $1.5 \mathrm{~mm}$ のステンレス管を、試料充填槽左端 より $25 \mathrm{~mm}$ および $350 \mathrm{~mm}$ の位置に、試料充填槽下 端より $25 \mathrm{~mm}$ の位置を始点として鉛直方向に $50 \mathrm{~mm}$ 間隔で 8 個ずつ設け、淡水の流線を観察す るためのトレーサ注入孔とした。また、傾斜面実 験では、トレーサ孔と同様のステンレス管を、水

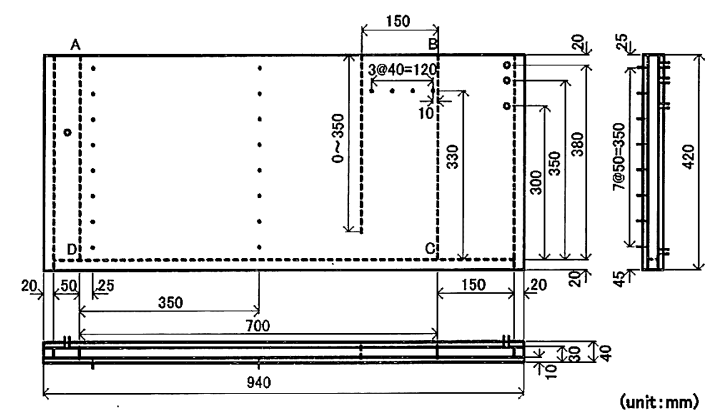

図 2 実験水槽図

Fig. 2 Plan of experimental aquarium 
槽裏面の試料充填槽下端より $330 \mathrm{~mm}$ 上方に試料 充填部右端より $130 \mathrm{~mm}$ の範囲で 4 個設け、斜面 上部の湛水を排水した。

\section{2 試料}

実験には、平均粒径0.6mmのガラスビーズを 用いた。なお、新しく購入したガラスビーズは強 い疎水性を示したため、実験に先立ち、洗剤で十 分に洗浄した。

用いたガラスビーズの物性值を表 1 に示す。な お、間隙率は別途作成した直方体容器を用い、本 実験と同様に落下法で試料を充填して測定した 值、透水係数も本実験と同様に落下法を用いて 鉛直カラムに試料を充填し、定水位法により測定 した值である。一方、縦分散長は、透水係数を測 定したガラスビーズ充填カラムに塩水トレーサを 流し、得られた破過曲線を用いて求めた值、横分 散長は本実験で観測されたトレーサ雲の縦横比よ り求めた值である。

\section{3 実験水}

淡水には密度 $0.999 \mathrm{~g} / \mathrm{cm}^{3}$ の水道水を使用し、塩 水には水道水に食塩を溶解させたものを用いた。 なお、水平面実験では、予備実験において塩水の 密度を通常の海水の密度と同程度としたところ、 塩水浸入の規模が小さく、塩水浸入の変化がとら えにくかったため、塩水密度を $1.058 \mathrm{~g} / \mathrm{cm}^{3}$ に調整 した。しかし、傾斜面実験では、塩水密度を通常 の海水密度と同程度とした場合でも、塩水浸入の 変化を十分にとらえることができたため、塩水密 度は $1.030 \mathrm{~g} / \mathrm{cm}^{3}$ に調整した。また、塩水浸入状況 を可視的に計測するため、試料への吸着が無く、 低濃度でも識別が可能なウラニン（別称フルオ レッセンソーダ、 $\left.\mathrm{C}_{20} \mathrm{H}_{10} \mathrm{Na}_{2} \mathrm{O}_{5}\right)$ を用いて塩水を着

\section{表 1 試料の物性值}

Table 1 Characteristics of glass beads

\begin{tabular}{|c|c|}
\hline 間隙率 $(-)$ & 0.378 \\
\hline $\begin{array}{c}\text { 透水係数 } \\
(\mathrm{mm} / \mathrm{s})\end{array}$ & 3.35 \\
\hline 縦分散長 $(\mathrm{mm})$ & 1.097 \\
\hline 横分散長 $(\mathrm{mm})$ & 0.022 \\
\hline
\end{tabular}

色した。

一方、淡水の流動状況を調べるため、後述の各 実験で定常状態に達した後、充填槽パネル前面の トレーサ注入孔よりウラニンを溶解させた淡水を 注入し、流線を測定した。

\section{3. 実験方法}

実験装置本体への試料充填に際しては、いずれ の実験も落下法により試料が均一になるように細 心の注意を払った。なお、水平面実験では試料上 面を水平に、また傾斜面実験では試料上面が淡水 槽境界位置で水槽下部より $400 \mathrm{~mm}$ 、塩水槽境界 位置で水槽下部より $300 \mathrm{~mm}$ （試料上面の勾配は 1/7）となるように、傾斜をつけて試料を充填し た。また、試料充填後のアクリル板の変形を防止 するため、万力を用いてアクリル板上面中央部を 固定した。

各実験の準備段階では、試料充填槽内に気泡が 残らないよう、淡水でゆっくりと試料を飽和させ ていき、ついで塩水槽下部より塩水を少量ずつ注 入して塩水槽内の淡水を塩水と置換させた。

水平面実験では計 6 種類の、また傾斜面実験で は計 7 種類の実験を実施した。実施した各実験の 条件を表 2 に示す。まず、水平面実験では、最初 に不完全貫入壁のない状態で、塩水水位を低い状 態から高い状態へと段階的に変化させ、定常状態 に達した後に各塩水水位での塩水浸入状況を調べ る実験（A、B、C）を実施した。ついで、塩水槽 排水口が最も高い状態（水槽下部より $380 \mathrm{~mm}$ ) で、不完全貫入壁の深度を $350 \mathrm{~mm}$ から $300 \mathrm{~mm}$ 、 $250 \mathrm{~mm}$ 一と段階的に引き上げ、各塩水水位で定 常状態到達後の塩水浸入状況を調べる実験（D、 E、F）を実施した。

一方、傾斜面実験では、最初は不完全貫入壁を 設置せず、塩水槽排水口が $300 \mathrm{~mm}$ と最も低い状 態（ケース G）で実験を行い、定常状態になった 後にトレーサを注入して流線の観測を行った。 ケース Gの実験終了後、塩水槽排水口を $350 \mathrm{~mm}$ の位置に移し、やはり定常状態になった後にト レーサで流線の観測を行った（ケース $\mathrm{H})$ 。ケー ス $\mathrm{H}$ の実験終了後、今度は止水壁内側の湛水排 水孔を開け、傾斜面下部の湛水を部分的に排水し 
て、定常状態になった後にトレーサで流線の観測 を行った（ケース I)。さらに、ケースIの実験終 了後、塩水槽排水口を $380 \mathrm{~mm}$ の位置に移し、定 常状態になった後にトレーサで流線の観測を行っ た (ケース J)。

そして最後に、不完全貫入壁を設置した一連の 実験を行った。まず、350mm 位置の塩水槽排水 口を開口し、さらに湛水域排水孔を開いた状態 で、実験（ケース K）を行い、実験終了後、貫入 壁深度を段階的に変化させて、ケース Lおよび ケース $\mathrm{M}$ の実験を行った。

また、電気伝導度計などを用いて塩淡遷移領域 を正確に測定することは困難なことから、本実験 ではデジタル写真をもとに塩淡境界部を判別する こととし、水平面実験、傾斜面実験ともにデジ夕 ルカメラを用いて塩水浸入の経時変化を記録し た。具体的には、塩水浸入が定常状態に達した 後、計16のトレーサ孔からウラニンを注入し、適 当な時間間隔でアクリルパネル上のトレーサ雲の 先端部に当たる部位にマーカを貼りつけていき、 最後にデジタルカメラで水槽全体を撮影し、パソ
コンに各画像をとりこんでマーカの位置を特定 し、流線を描いた。

\section{4. 実験結果と考察}

\section{1 水平面実験}

\section{1 ) 不完全貫入壁が無い場合}

図 3 (a)、(b)、（c）に、それぞれケース A、B、 Cに対する実験結果を示す。なお、図中の○は不 定時間におけるトレーサの移動状況をマーキング したもので、実線はマーキング点を内挿して求め た流線で、破線は目視による塩淡境界である。 ケースAのように低位置の排水口を開口した場合 では、塩水浸入は発生しなかった。たたし、この ケースでも塩水槽下部で淡水の流れは塩水にブ ロックされるため、塩水槽に沿って上昇する淡水 の流れが発生している。排水口を $50 \mathrm{~mm}$ 上げた ケース B では塩淡界面は試料充填域下部で約 $80 \mathrm{~mm}$ 程度充填槽内に浸入し、排水口をさらに上 げて $380 \mathrm{~mm}$ としたケース Cでは塩淡界面は試料 充填域下部で約 $330 \mathrm{~mm}$ も充填槽内に浸入してい

表 2 実験種類と条件

Table 2 Conditions of experiments

\begin{tabular}{|c|c|c|c|c|c|c|}
\hline & Case & $\begin{array}{c}\text { 淡水水位 } \\
(\mathrm{mm})\end{array}$ & $\begin{array}{c}\text { 塩水排水口 } \\
(\mathrm{mm})\end{array}$ & $\begin{array}{c}\text { 不完全買入 } \\
\text { 壁深度 }(\mathrm{mm})\end{array}$ & $\begin{array}{l}\text { 排水 } \\
\text { 操作 }\end{array}$ & $\begin{array}{c}\text { 塩水密度 } \\
\left(\mathrm{g} / \mathrm{cm}^{3}\right)\end{array}$ \\
\hline \multirow{6}{*}{$\begin{array}{l}\text { 水 } \\
\text { 平 } \\
\text { 面 } \\
\text { 害 } \\
\text { 験 }\end{array}$} & A & 400 & 300 & - & 無し & 1.058 \\
\hline & B & 400 & 350 & - & 無し & 1.058 \\
\hline & $\mathrm{C}$ & 400 & 380 & - & 無し & 1.058 \\
\hline & $\mathrm{D}$ & 400 & 380 & 350 & 無し & 1.058 \\
\hline & E & 400 & 380 & 300 & 無し & 1.058 \\
\hline & $\mathrm{F}$ & 400 & 380 & 250 & 無し & 1.058 \\
\hline \multirow{7}{*}{$\begin{array}{l}\text { 傾 } \\
\text { 䈖 } \\
\text { 実 } \\
\text { 験 }\end{array}$} & G & 380 & 300 & - & 無し & 1.030 \\
\hline & $\mathrm{H}$ & 380 & 350 & - & 無し & 1.030 \\
\hline & I & 380 & 350 & - & 有り & 1.030 \\
\hline & $\mathrm{J}$ & 380 & 380 & - & 有り & 1.030 \\
\hline & $\mathrm{K}$ & 380 & 350 & 350 & 有り & 1.030 \\
\hline & $\mathrm{L}$ & 380 & 350 & 300 & 有り & 1.030 \\
\hline & M & 380 & 350 & 250 & 有り & 1.030 \\
\hline
\end{tabular}


る。このように、塩水槽におけるわずかな塩水水 位の上昇により、塩水くさびは大きく拡大するこ とが分かる。なお、ケース B と Cで塩水浸入領域 の面積を比較すると、Cでは B の10倍以上にも なっている。また、図 3 より塩水楔が大きくなる につれて、上昇流も卓越してくることが分かる。

\section{2 ) 不完全貫入壁が有る場合}

境界条件がケースC と同一で、不完全貫入壁を

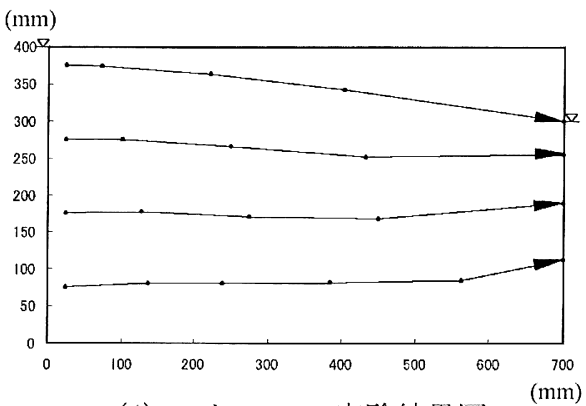

（a）ケース A 実験結果図

【塩水排水口 $300 \mathrm{~mm}$ ，貫入壁無し】

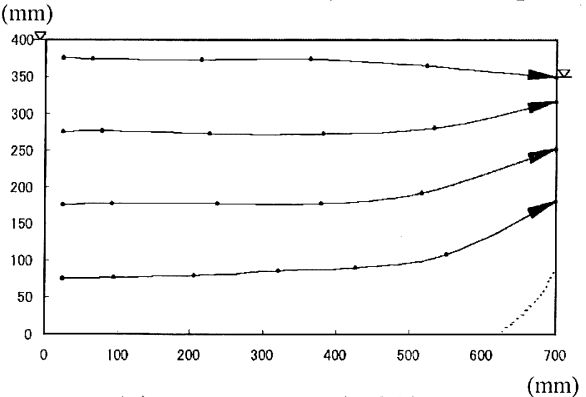

(b) クース B 実験結果図

【塩水排水口 $350 \mathrm{~mm} ，$ 貫入壁無し】

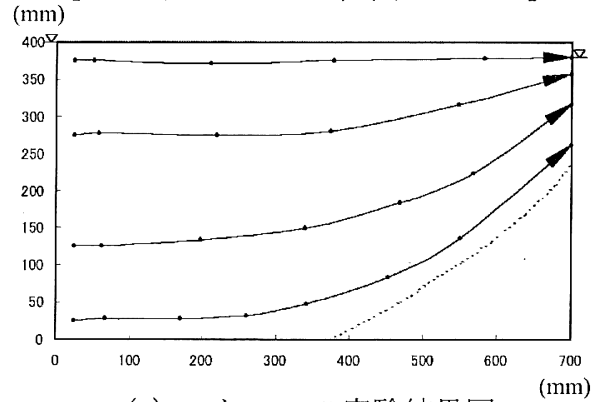

（c）ケース C 実験結果図

【塩水排水口 $380 \mathrm{~mm}$ ，貫入壁無し】

図 3 水平面実験結果【ケース $\mathrm{A} \sim \mathrm{C}$ 】

Fig. 3 Results of experiments with flat surface 【Case $A \sim C$ C
設置したケース D、E、Fの実験結果をそれぞれ 図 4 (a)、（b）、（c）に示す。なお、塩水排水位置 (380mm) から水槽下部までの距離を基準とする 不完全貫入壁の貫入梁度は、ケース D で $87 \%$ 、 ケース Eで74\%、ケース F で61\%である。

図 3 （c）と比較することにより、貫入壁が塩水 浸入阻止効果を有し、貫入壁深度が大きくなるほ どその効果が大きくなることがわかる。なお、淡

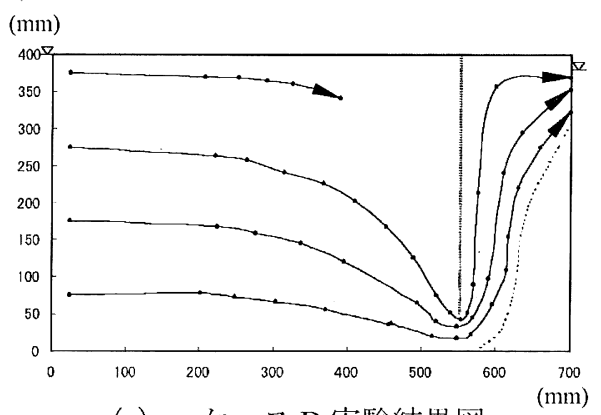

（a）ケース D 実験結果図

【塩水排水口 $380 \mathrm{~mm}$ ，貫入壁深度 $87 \%$ 】

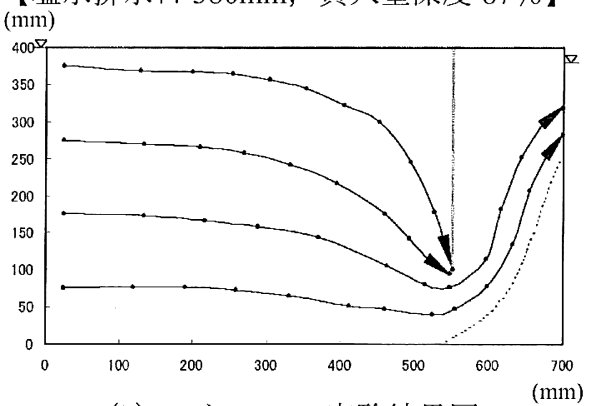

（b）ケース $\mathrm{E}$ 実験結果図

【塩水排水口 $380 \mathrm{~mm}$, 貫入壁深度 $74 \%$ 】 (mm)

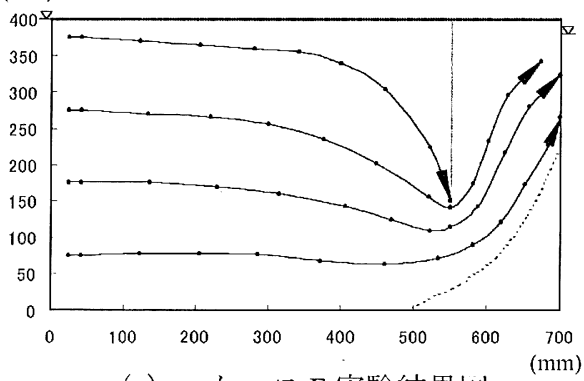

(c) ケース $\mathrm{F}$ 実験結果惴

【塩水排水口 $380 \mathrm{~mm}$ ，貫人壁深度 $61 \%$ 】

図 4 水平面実験結果【ケース D F】

Fig. 4 Results of experiments with flat surface 【Case D F】 
水の流れは貫入壁左側でいったん降下して貫入壁 を回り达んだ後、反転して上昇流となっている。 試料充填部と塩水槽の境界から塩水楔先端まで の長さを塩水浸入長とし、不完全貫入壁の貫入深 度と最大塩水浸入長との関係を示したものが図 5 である。不完全貫入壁の貫入深度が大きくなるほ ど、塩水浸入長は小さくなる。一方、図 6 は貫入 率と塩水浸入領域の大きさを比較したものであ る。塩水浸入領域では不完全貫入壁の貫入深度が

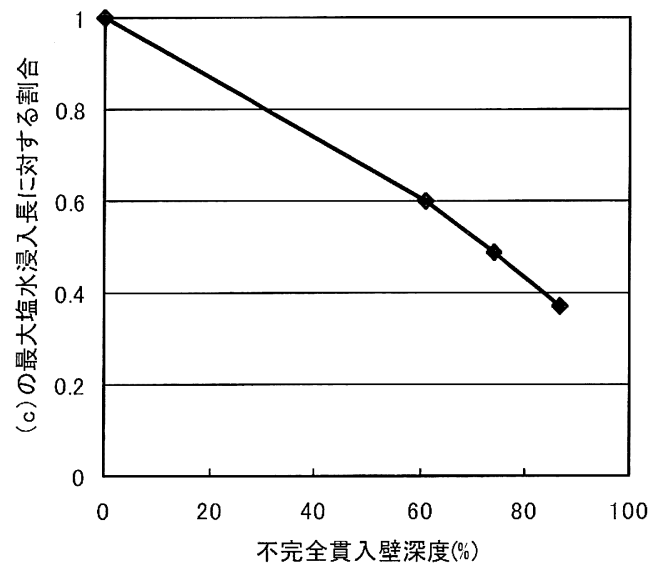

図 5 不完全貫入壁の深度と最大塩水浸入長の関係

Fig. 5 Relationship between length of imperfect barrier wall and maximum length of saltwater intrusion

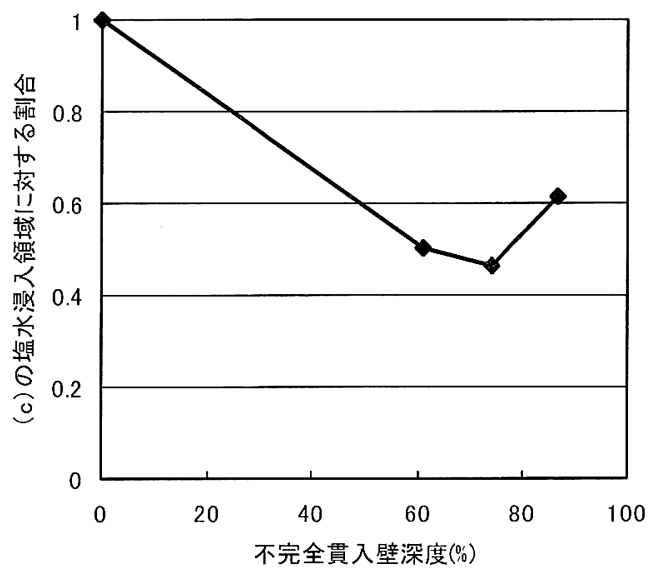

図 6 不完全貫入壁の深度と塩水浸入領域の関係

Fig. 6 Relationship between length of imperfect barrier wall and area of salt-water intrusion
大きすぎると淡水による塩水のフラッシュ効果が 小さくなり、塩水浸入領域は逆に増加してしまう ことがわかる。

\section{2 傾斜面実験}

\section{1 ）不完全貫入壁および湛水排水が無い場合}

図 7 (a) および（b）に、それぞれケース G、 $\mathrm{H}$ の実験結果を示す。塩水排水口が $300 \mathrm{~mm}$ と低 い位置にあるケース Gでは、ケース A と同様に試 料充填域下部には塩水楔は発生しなかった。しか し、試料充填部と塩水槽の境界上部に設けた遮水 壁の内側には水槽下部より $320 \mathrm{~mm}$ の位置まで地 表水が湛水した。淡水の流線をみると、試料上部 では淡水は傾斜面に浸出し（最上部の 2 本の流線 を参照)、上から 3 本目の流線は淡水面に向かっ て一旦上昇するものの、淡水域下部で反転降下し て塩水槽へ流出している。

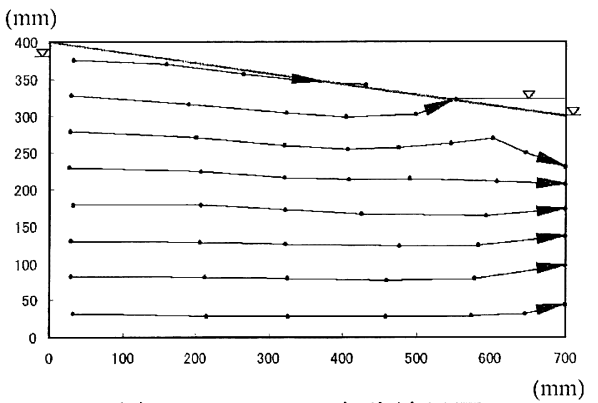

（a）ケース G 実験結果㘠

【塩水排水口 $300 \mathrm{~mm}$, 排水無し, 貫入壁無し】

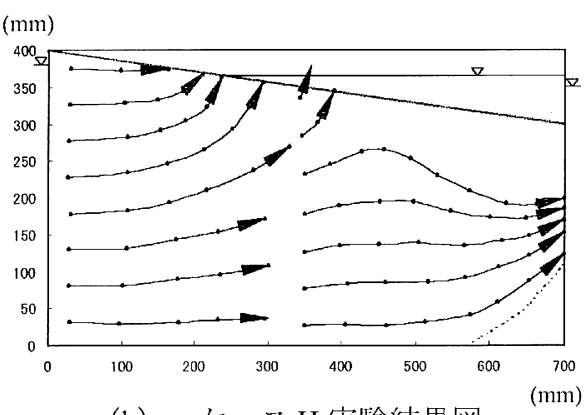

（b） ケース $\mathrm{H}$ 実験結果図

【塩水排水山 $350 \mathrm{~mm}$, 排水無し, 貫人壁無し】

図 7 傾斜面実験結果【ケース G、H】

Fig. 7 Results of experiments with inclined surface [Case G, H] 
ケース Gで定常状態に到達した後に、塩水排水 孔の位置を $300 \mathrm{~mm}$ から $350 \mathrm{~mm}$ に変化させたケー ス $\mathrm{H}$ では、試料上面の底部は塩水槽排水位置よ り下部に位置することになる。その結果、約 $130 \mathrm{~mm}$ 程度の塩水浸入が発生し、遮水壁内側に は水槽下部より $362 \mathrm{~mm}$ の位置まで地表湛水が発 生した。一方、淡水の流線をみると、試料左上部 に大規模な上昇流が発生して試料表面に浸出して おり、いったん斜面上に湛水した淡水も再び充填 槽内へ浸入する流れが発生している。また試料右 下部では塩水楔による上昇流もみられ、試料中間 部ではケース $\mathrm{G}$ と同様に蛇行した流れが見られ る。

\section{2 ) 不完全貫入壁が無く湛水排水が有る場合}

図 8 (a) および（b）に、それぞれケース I、J の実験結果を示す。ケースIは、ケース H の斜面 上の湛水を遮水壁内側に設けた排水孔より排水し

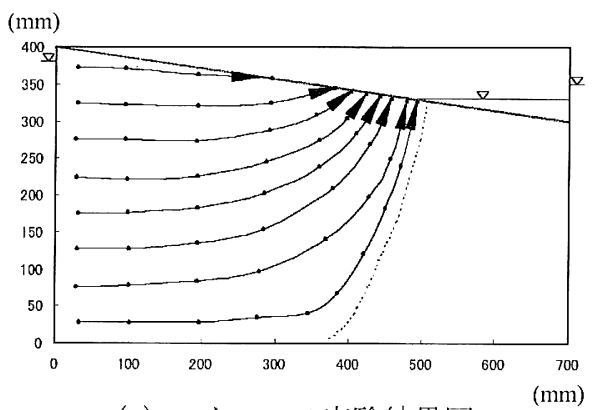

（a）ケース I 実験結果図

【塩水排水口 $350 \mathrm{~mm}$, 排水有り, 貫入壁無し】

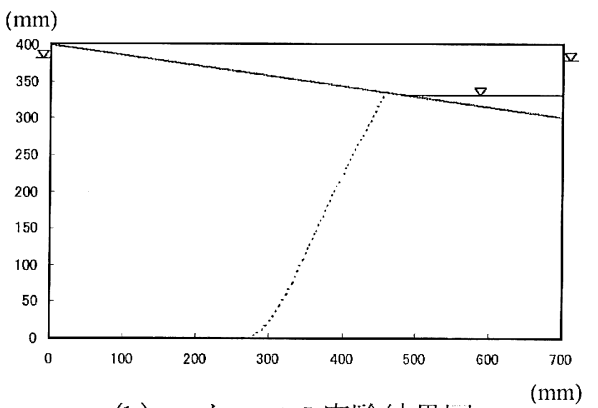

(b) ケース J 实験結果㥗

【塩水排水口 $380 \mathrm{~mm}$, 排水有り, 貫入壁無し】

図 8 傾斜面実験結果【ケースリ、」】

Fig. 8 Results of experiments with inclined surface [Case I, J】
た場合である。塩水は試料内部に深く浸入すると ともに、試料表面にも浸出している。すなわち、 湛水の一部を排水孔より排水したことにより、遮 水壁内側のポテンシャルが低下し、さらなる塩水 浸入を誘発して浸入域が拡大したことがわかる。 また、マリオットから供給される淡水は塩水槽へ は流出せず、全て湛水排水孔から排水されてい る。ちなみに、遮水壁内側の排水孔からの排水量 は $1.096 \mathrm{~cm}^{3} / \mathrm{sec}$ であった。また、塩淡界面にそっ てケース $\mathrm{H}$ より顕著な淡水の上昇流が発生して いることがわかる。

図 8 （b）は、塩水槽の排水口を380 $\mathrm{mm}$ に上げ たケース J の実験結果である。なお、本ケースで は、トレーサによる流線観察を行っていないた め、塩淡境界線のみ示してある。塩水は充填槽底 部でケース Iより約 $100 \mathrm{~mm}$ 深く試料内部に浸入し ており、遮水壁内側の湛水排水孔での排水量は

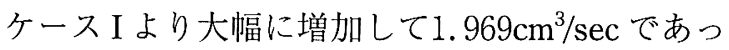
た。本ケースは、塩水面の上昇が塩水浸入を誘発 して浸入領域を拡大させ、試料表面への浸出量も 著しく增大することを示している。マリオットか ら供給される淡水はケース I と同様に塩水槽へは 流出せず、全て湛水排水孔から排水されている。 な资淡水水位も塩水面の位置もいずれも $380 \mathrm{~mm}$ であり、高さ330mm の位置で湛水排水が 行われなければ浸透流は塩水側から淡水側へ向か うが、湛水排水を行ったことにより、淡水も塩水 もすべて試料上部の斜面から流出していることに 注意したい。

\section{3 ) 不完全貫入壁および湛水排水がある場合}

最後に、斜面湛水を排水した結果塩水浸入領域 が非常に大きくなったケース Iの境界条件で、不 完全貫入壁を設けた実験であるケース K、L、M の実験結果を図 9 (a)、（b）、（c）にそれぞれ示 す。なお、ケースIは、ケース $\mathrm{H}$ の斜面上の湛水 を遮水壁内側に設けた排水孔より排水した場合 で、塩水排水位置 $(350 \mathrm{~mm})$ から水槽下部までの 距離を基準とする不完全貫入壁の貫入深度は、 ケース K で $86 \%$ 、ケース L で72\%、ケース M で 58\%である。

ケース K、L、Mでもケース D、E、Fと同様に 不完全貫入壁の設置により塩水浸入領域は大幅に 縮小している。しかし、遮水壁内側の斜面では湛 
水排水孔位置まで湛水するだけでなく、不完全貫 入壁の上流側斜面にも淡水が貯留する結果となっ た。ちなみに、不完全貫入壁上流部の貯留淡水水 位は、ケース K で372mm、ケース L で $370 \mathrm{~mm}$ 、 ケース M で $368 \mathrm{~mm}$ であり、不完全貫入壁の設置 深度が深いほど貯留淡水水位は大きくなることが

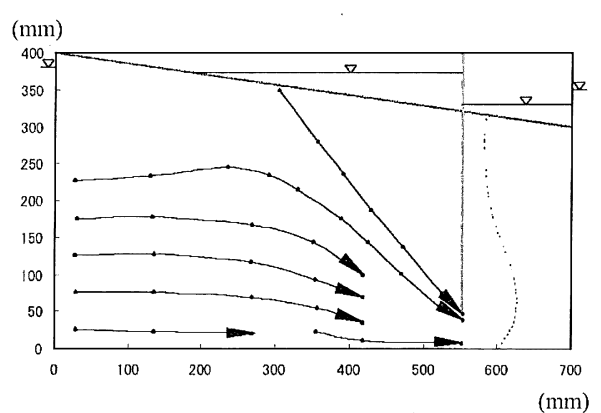

(a) ケース $\mathrm{K}$ 実験結果図

【塩水排水口 $350 \mathrm{~mm}$, 排水有り，貫入壁深度 $86 \%$ 】

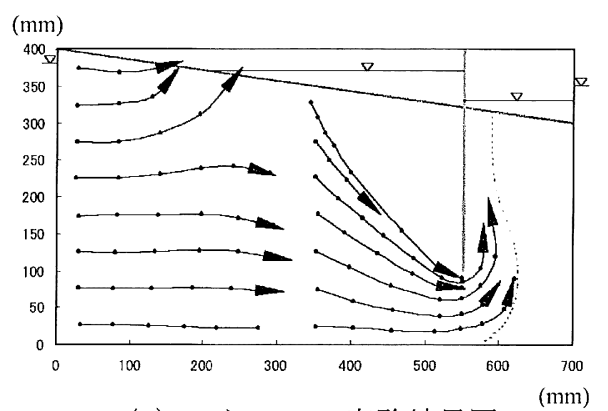

（b） ケース L 実験結果図

【塩水排水口 $350 \mathrm{~mm}$, 排水有り, 貫入壁深度 $72 \%$ 】

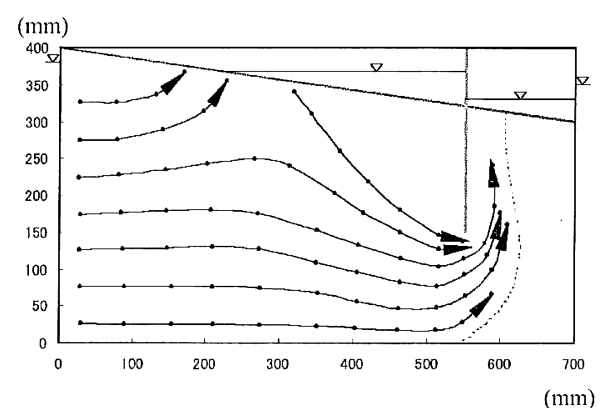

(c) ケース $\mathrm{M}$ 尖験結果図

(mm)

【塩水排水口 $350 \mathrm{~mm}$, 排水有り，買入壁深度 $58 \%$ 】

図 9 傾斜面実験結果【ケース $\mathrm{K} \sim \mathrm{M}$ 】

Fig. 9 Results of experiments with inclined surface 【Case $\mathrm{K} \sim \mathrm{M}$ 】
分かった。

なお、今回は不完全貫入壁を地上部まで延長さ せたため貫入壁上流部に湛水が発生したが、今後 は貫入壁上部が地下にある場合の塩水浸入阻止効 果や湛水状況も検討する必要がある。

\section{5. おわりに}

地球温暖化に伴う海面上昇が、ゼロメートル地 帯の地下水環境に与える影響を調べるため、平均 粒径0.6mm のガラスビーズを充填した水槽を用 いて塩水浸入実験を実施した。実験においては、 試料上面を平坦にした場合と傾斜させた場合、塩 水浸入阻止のための異なる貫入深度を持つ止水壁 を用いた場合と用いない場合、および傾斜面実験 では遮水壁の内側に湛水排水孔を設けた場合と設 けない場合のケース分けを行った。本実験的研究 により得られた知見を以下に要約する。

$1 ）$ 水平面実験より、塩水面の上昇は塩水浸入 領域を拡大させるが、不完全貫入壁により塩水浸 入を緩和させることができる。

2 ）傾斜面実験より、塩水面が上昇するとゼロ メートル地帯では地表湛水量が増大する。

3 ）傾斜面実験で、地表湛水を排水すると、塩 水浸入が誘発されて塩水浸入領域が拡大寸る。

4) 傾斜面実験で、不完全貫入壁を設置し、地 表湛水を排水すると、塩水の浸入は軽減できるが 貫入壁の内側にも地表湛水が発生する。

本報では、矩形の水槽を用いた均質な多孔体に 対して行った塩水浸入実験の結果をとりまとめた ものであるが、複雑な地層構造をもつ首都圈など の被害想定地域に対して海面上昇が塩水浸入現象 と関連する環境問題にもたらすと考えられる影響 は基本的には同質である。たた、このような現実 の問題を詳細に分析し海面上昇の影響を予測する には、精度の高い充分な現地データと精密な数值 解析モデルが必要となる。現在、本研究で実施し た実験結果をベンチマークに、塩水浸入解析のた めの密度依存地下水流の数值解析手法を開発して いるところであり、今後は地中海に面したトルコ のチュクロバ平野に開発中の数值解析モデルを適 用する予定である。 


\section{謝 辞}

本研究は、大学共同利用機関法人人間文化研究 機構総合地球環境学研究所の研究プロジエクト 「乾燥地域の農業生産システムに及ぼす地球温暖 化の影響」の一環として実施したものである。ま た、実験の実施に当たっては信州大学の豊田富晴 技官より有益な助言をいただいた。ここに、記し て関係各位に感謝の意を表します。

\section{参考文献}

環境庁地球環境部監修（1994）：地球環境の行方。中央 法規、81 95.

村下敏夫（1982）: 本邦における地下水の塩水化. 地質 調査書月報、33、479 530.
細川土佐男 - 籾井和朗 $\cdot$ 神野健二 ·上田年比古 $\cdot$ 伊藤敏 朗（1989）：被圧帯水層における塩水混合域の分散特 性に関する実験及び数値解析による検討．第33回水 理講演会論文集、193 198.

IPCC (2001): Technical Summary, Climate change 2001; Impacts,adaptation,and Vulnerability.

TNO (2003): Salinisation of the Dutch groundwater flow system-Modeling density-dependent groundwaterflow in coastal areas. Spetial Information, 1-6.

Essink, G.O. and F. Schaars (2002): Impact of climate change on the groundwater system of the water board of Rijnland, The Netherlands. Proceedings of the $17^{\text {th }}$ Salt water intrusion meeting, Delft, the Netherlands.

（受付：2004年 5 月21日、受理：2004年12月 4 日） 